\author{
Abstracta Iranica \\ Abstracta Iranica Revue bibliographique pour le domaine irano-aryen \\ Volume 37-38-39 | 2018 \\ Comptes rendus des publications de 2014-2016
}

\title{
Wolfram KLEISS. Geschichte der Architektur Irans
}

\author{
Iván Szántó
}

\section{(2) OpenEdition}

\section{Journals}

Electronic version

URL: http://journals.openedition.org/abstractairanica/51403

DOI: 10.4000/abstractairanica.51403

ISBN: 1961-960X

ISSN: 1961-960X

Publisher:

CNRS (UMR 7528 Mondes iraniens et indiens), Éditions de l'IFRI

Electronic reference

Iván Szántó, «Wolfram KLEISS. Geschichte der Architektur Irans », Abstracta Iranica [Online], Volume 37-38-39 | 2018, document 33, Online since 10 March 2018, connection on 28 October 2020. URL: http://journals.openedition.org/abstractairanica/51403 ; DOI : https://doi.org/10.4000/ abstractairanica. 51403

This text was automatically generated on 28 October 2020

Tous droits réservés 


\title{
Wolfram KLEISS. Geschichte der Architektur Irans
}

\author{
Iván Szántó
}

\section{REFERENCES}

Wolfram KLEISS. Geschichte der Architektur Irans. (Archäologie in Iran und Turan), Vol. 15. Berlin: Dietrich Reimer, 2015, 461 p., 113 colour illustrations, 754 black and white figures. ISBN: 978-3-496-01542-0

1 Encompassing the results of over fifty years of archaeological and architectural fieldwork, this volume, dedicated to the author's lifelong companion and erudite reader Lisselotte Soltani, offers a consummate presentation of key findings during a rich scholarly career. It endeavours to trace the formation of building techniques, types, and functions over the course of three millennia, mostly within the modern boundaries of Iran. The aim and ambition of this monumental work conjure up the tradition of 20th-century surveys, which, in turn, emerged from the "Grundrisse" of the 1800s, and served to outline various cultural areas in monographic form. In contrast, however, with some of these earlier monographs, Kleiss largely refrains from drawing up evolutionary tendencies and instead of a narrative framework, he introduces the material in a way that is more encyclopaedic than monographic. Apart from the somewhat dismaying absence of indexes, one can detect this approach also in the quantitative equilibrium between text and image in the book: without doubt it is the hundreds of comparative in-text illustrations which ensure this book achieving the status of the arguably most comprehensive single-volume treatment of Iranian architecture. The excellent range of photographs from the author's archives notwithstanding, most readers will be especially captivated by the unique series of linedrawings by the author, often evocative artworks and austere scientific renderings at the same time, expressing the spatial aspects of architectural complexes such as Persepolis or Takht-i Sulaymān in a more tangible way than aerial photography can do. 
The photographs and visual reconstructions are complemented by cross-sections, floorplans, and architectural elements, arranged in explanatory, typological sequences.

2 The book is arranged in ten, slightly overlapping, parts. Part 1 locates the history of built environment in its slowly changing natural surroundings and investigates building materials (especially wood and adobe), before moving on to simple, utilitarian constructions: walls, bridges, rock-cut structures (from Pre-Achaemenid to Safavid times), dams, water conduits, aqueducts, tumuli and sarcophagi, including lion-shaped and Christian tombstones.

3 Part 2 comprises a through overview of architecture proper from the 1st millennium BCE to the early Islamic period, including Jewish, Zoroastrian, and Christian sites, and with a particular emphasis on pre-state, Elamite, Urartian, Median, Achaemenid, Parthian, and Sasanian buildings, in some cases viewed from a trans-boundary perspective (i.e., Urartu), in other cases more restricted to modern Iran (i.e., Arsacid architecture). Part 3 covers Western-influenced architecture, although it is mostly limited to Portuguese fortresses in the south to 19th-century examples of Frenchinspired military engineering in the north (Ahar and Khūy), and also refers to gates and gate-like constructions, such as the Šāhyād (Āzādī) Tower in Tehran. Part 4 discusses urban and rural caravanserais, as well as post-houses (čāpārkhāna) and similar buildings. Part 5 is about bridges and dams, baths, watermills and windmills, bazars, pigeon towers, reed-covered oval houses and tower houses of the Caspian region, supplemented, like elsewhere, with numerous drawings, cross sections, and plans.

4 Part 6 explores early modern architecture and urbanism, as well as traditional urban and rural housing. Part 7 continues with an eclectic range of residences from the Islamic period (reused Pre-Islamic structures, garden pavilions, city residences, and Assassin castles). This part also abounds in drawings of architectural decoration, including limestone column capitals (nos. 619-26) and other fittings. The subject of Part 8 is the religious architecture of the Islamic period: madrasas, monasteries, husayniyas, mușallās, minarets (nos. 662-4), central domed buildings, imāmzādas and other funerary complexes, tomb towers, and, for some reason, observatories. Mosques, however, are reserved for the next part of the book (Part 9) which also deals with topics ranging from Safavid Isfahān to wind towers, or the Ganj 'Alī Khān complex of Kirmān, all supplemented with detailed floor plans. The last part (no. 10) provides an overview of modern Iranian architecture, both public and private, focusing on Tehran and Šīrāz, and also presenting typical upper-middle-class Tehran apartments of the mid- and late-20th century.

5 The main text is followed by German, English, and Persian summaries, and a bibliography (pp. 420-431), in which a near-complete list of publications by Wolfram Kleiss is also found. 


\section{AUTHORS}

IVÁN SZÁNTÓ

Eötvös Loránd University, Budapest \& Austrian Academy of Sciences, Vienne 